ACTA MYCOLOGICA

Vol. 44 (2): 139-149

2009
Dedicated to Professor Krystyna Czyżewska

in honour of 40 years of her scientific activity

\title{
Lichens of abandoned zinc-lead mines
}

\author{
URSZULA BIELCZYK ${ }^{1}$, MONIKA JEDRZEJCZYK-KORYCIŃSKA ${ }^{2}$ \\ and JOZEF KISZKA ${ }^{1}$
}

${ }^{1}$ Institute of Biology, Pedagogical University of Kraków, Podbrzezie 3

PL-31-054 Kraków, bielczyk@up.krakow.pl

${ }^{2}$ Department of Plant Systematics

University of Silesia, Jagiellońska 28, PL-40-032 Katowice, mjedrzej@us.edu.pl

Bielczyk U., Jędrzejczyk-Korycińska M., Kiszka J. : Lichens of abandoned zinc-lead mines. Acta Mycol. 44 (2): 139-149, 2009.

A list of lichens from areas of zinc-lead ores in Southern Poland and a review of the characteristic lichen biota of these sites is provided. In spite of the devastated and heavy metal contaminated environment, a highly diverse epigeic and epilithic lichen biota was found, including species characteristic of various anthropogenic habitats, particularly zinc and lead enriched substrates (Diploschistes muscorum, Steinia geophana, Sarcosagium campestre, Vezdaea aestivalis and V. leprosa). Also, the high-mountain species Leucocarpia biatorella, as well as very rare in Europe Thelocarpon imperceptum, and several species categorized as very rare, endangered and protected in Poland were recorded. Crustose lichens are the most abundant; among fruticose forms Cladonia spp. predominate and Stereocaulon incrustatum is common.

Key words: lichenized fungi, anthropogenic habitats, heavy metals, galena, Silesian-Kraków Upland

\section{INTRODUCTION}

The largest resources of zinc and lead ores in Poland occur in Silesian-Krakow monocline, where they have been mined and processed since the Middle-Ages. Those deposits are often bound to the Triassic carbonate rocks - ore-bearing dolomites (Żabiński 1960). The oxidized zinc and lead ores (galena) are often defined as galmani (Żabiński 1978). Due to the mining and metallurgy in southern Poland, numerous scars to the landscape have been developed such as excavations (voids), shafts, mining adits and mine waste heaps (Molenda 1963). Such activities have significantly influenced the status of surface and ground water, soils, and consequently the flora and fauna; in addition, the presence of heavy metals (zinc, lead, cadmium) considerably influenced organisms, such species as colonize such habitats have various 
features which help them to adapt to these adverse, or even toxic, conditions. Zinc and lead ores are colonized those organisms with a wide tolerance of environmental stress, producing unique communities with an interesting biology (Jędrzejczyk 2004; Szarek-Łukaszewska, Grodzińska 2008).

In habitats contaminated by heavy metals, lichens, usually accompanied by mosses, are of great importance, forming unique plant communities (Wirth 1972; Purvis, Halls 1996; Paus 1997; Cuny et al. 2004). Thus, mining or metallurgy sites provide a particular field laboratory to follow natural processes of interest to lichenologists in terms of their taxonomy, physiology, threats and protection, monitoring abilities, etc. In Europe, 291 lichen species have been noted from habitats rich in metals such as iron, copper, zinc, lead, chromium, nickel (Purvis, Halls 1996; Heibel 1999; Cuny et al. 2004). Lichens often thrive on substrates rich in zinc and lead, and some genera such as Gyalideopsis, Sarcosagium, Steinia and Vezdaea appear to be limited to such habitats and can be used as good indicators of $\mathrm{Zn}$ and $\mathrm{Pb}$ (Cuny et al. 2004). Some new species have been described from the $\mathrm{Zn}$ and Cd polluted areas, such as Micarea confusa (Coppins, van den Boom 1995), Pyrenocollema chlorococcum (Aptroot, van den Boom 1998) and Coppinsia minutissima (Lumbsch, Heibel 1998).

Limited information on species composition and their behaviour on post-exploitation areas (e.g., Seaward, Bylińska 1980; Kiszka 2003), but there has been no detailed documentation of lichen species from zinc and lead ores areas in Poland. The results presented below sum up current knowledge and establish a basis for future studies on the characteristic lichen biota of abandoned zinc-lead mining areas in Poland, as well contributing to our knowledge of species distribution.

\section{STUDY AREA}

Studies were carried out in five sites of former mining and metallurgical sites based on zinc and lead ores, where there has been no subsequent development and spontaneous succession of vegetation has occurred (Fig.1). Studies were conducted on the three mineral deposit zones of the Silesian-Kraków monocline: Tarnowskie GóryBytom area (two sites in Tarnowskie Góry), Chrzanów-Jaworzno area (grassland in Jaworzno-Długoszyn and in Balin near Chrzanów), and Siewierz-Olkusz area (in Bolesław). Study sites vary in age and nature of their development.

Bolesław (Fig.1, I). Soil-rock bank and grassland $\left(4.5 \mathrm{~km}^{2}\right)$ covered partially by shrubs and trees (coniferous and sporadically deciduous). On reasonably large area was planted with pine during restoration work. In the S-E part, an area is protected as "ecological arable land" [in Polish: użytek ekologiczny] due to the occurrence of Biscutella laevigata.

"Warpie" Wood in Balin near Chrzanów (Fig.1, II). This study area $\left(1.8 \mathrm{~km}^{2}\right)$ is covered by pine forest, with some birch and larch. Forest bottom morphology suggest a post-mining character of the area. Part of the study site is open grassland, with blackthorn shrubs. Some arable land is present in the vicinity.

Jaworzno Długoszyn (Fig.1, III). This study area $\left(3.5 \mathrm{~km}^{2}\right)$ is situated is within the city limits of Jaworzno, where signs of zinc-lead ore mining are still visible between 


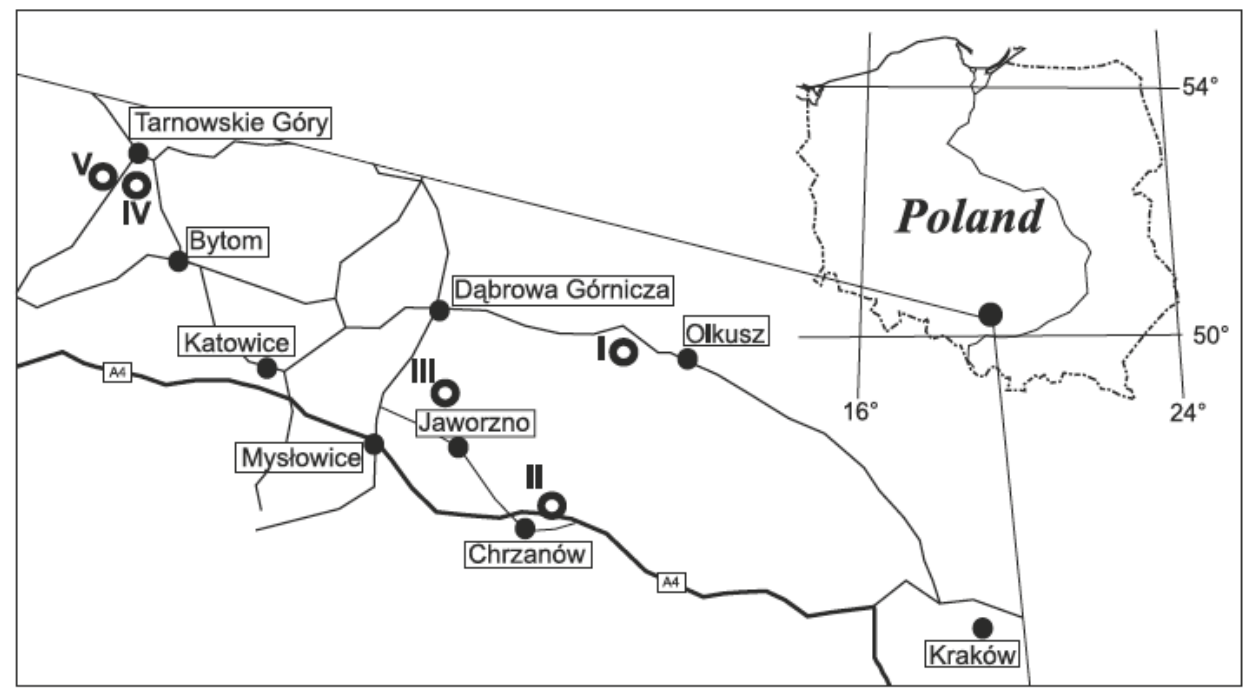

Fig. 1. Location of the investigated areas:

I - Bolesław next to Olkusz; II - "Warpia" Wood in Balin next to Chrzanów; III - Jaworzno-Dlugoszyn; IV - Tarnowskie Góry dolomite heap; V - Tarnowskie Góry "Planeta" Wood.

built-up areas. Part of the site is covered by mixed forest, part by grassland, and part transformed into farmland.

Tarnowskie Góry - dolomite heap (Fig.1, IV). This study area $\left(1.5 \mathrm{~km}^{2}\right)$ is essentially a mining spoil heap located in a place where 120 years of drilling for the "Fryderyk" mine undertaken. The heap was formed of the ore-bearing dolomites, which were processed (sorted and rinsed) to provide zinc-lead ore (containing silver) and iron ore (limonite). It is surrounded by farmlands and there are two inlets of the drainage shaft in the vicinity.

Tarnowskie Góry - "Planeta" Wood (Fig.1, V). This study area $\left(1.2 \mathrm{~km}^{2}\right)$ of postmining of zinc-lead ores, situated on the city limits of Bytom and Tarnowskie Góry, is covered by degenerated forest, with a small, anthropogenic pond and some open ground of mainly by grassland.

Soils of zinc-lead ores from former mining and metallurgy are characterized by the presence of primary and secondary ores of zinc, lead and cadmium. Most soils here are skeletal and the rock soils are composed of clay and silt, with no profile differentiation. Such soils are characterized by their low nitrogen and phosphorus content.

All study areas have elevated concentration of heavy metals, highest zinc concentration exceeding $46000 \mathrm{mg} / \mathrm{kg}$, lead $24500 \mathrm{mg} / \mathrm{kg}$, and cadmium $500 \mathrm{mg} / \mathrm{kg}$ (Jędrzejczyk 2004; Jędrzejczyk-Korycińska 2006). Bioaccessibility varies according to the metal form.

A major edaphic determinant of spontaneous vegetation development is water shortage or availability. A specific feature of the studied areas is the tendency to the soil surface to rapidly over-dry. Such areas are often subjected to strong solar insolation and strong winds (Dobrzańska 1955; Wierzbicka 2002). 


\section{MATERIAL AND METHODS}

Data gathered in 2002-2004 were analyzed, the collected species being assigned to appropriate morphological and ecological groups. Collected material was analysed according to standard morphological and anatomical methodology. In this paper we follow Fałtynowicz (2003) lichen nomenclature, excluding the genus Coenogonium (Kauff, Büdel 2005), and Mirek et al. (2002) for plant nomenclature. Documentation and collected material is deposed in the Herbarium of the Department of Biology, Institute of Biology, Pedagogical University of Kraków (KRAP-L).

For the identified species, their frequency on the study sites was determined according to three categories: 1 - rare (1-3 records), 2 - frequent (4-10 records) and 3 - common (over 10 records) on one observed sites.

\section{RESULTS}

The number of known lichen species from the post-mining, ore-bearing areas of the Silesian-Kraków Upland reached 89 taxa, of which 76 are listed in Table 1.

Table 1

Lichen species in studied sites

B - Bolesław, W - "Warpia" Wood in Balin, JD - Jaworzno-Długoszyn, TGD - Tarnowskie Góry dolomite spoil heap, TGP - Tarnowskie Góry "Planeta" Wood

\begin{tabular}{|c|c|c|c|c|c|c|c|}
\hline \multirow[t]{2}{*}{ No } & \multirow[t]{2}{*}{ Taxon } & \multirow{2}{*}{$\begin{array}{c}\text { Substrate } \\
\text { preferency/ies }\end{array}$} & \multicolumn{5}{|c|}{ Frequency scale } \\
\hline & & & B & W & JD & TGD & TGP \\
\hline 1. & Agonimia tristicula (Nyl.) Zahlbr. & soil, bryophytes & 1 & & & & \\
\hline 2. & Arthonia exilis (Flörke) Anzi & Thymus sp. & 1 & & & & \\
\hline 3. & Arthonia lapidicola (Tayl.) Branth \& Rostr. & pebbles & 1 & & & & \\
\hline 4. & $\begin{array}{l}\text { Aspicilia contorta (Hoffm.) Kremp. subsp. } \\
\text { hoffmanniana Ekman \& Fröberg }\end{array}$ & stones & & 1 & & & \\
\hline 5. & Aspicilia moenium (Vain.) G. Thor \& Timdal & stones & 1 & & & & \\
\hline 6. & $\begin{array}{l}\text { Bacidia bagliettoana (A. Massal. \& De Not.) } \\
\text { Jatta }\end{array}$ & soil, bryophytes & 3 & & 3 & 3 & \\
\hline 7. & Bacidina phacodes (Körb.) Vězda & soil, bryophytes & 2 & & 2 & 2 & \\
\hline 8. & Baeomyces rufus (Huds.) Rebent. & soil & & 3 & & 2 & \\
\hline 9. & Caloplaca holocarpa (Hoffm.) A. E. Wade & stones, pebbles & & & 1 & & \\
\hline 10. & Candelariella aurella (Hoffm.) Zahlbr. & stones, pebbles & 2 & 2 & 3 & 2 & \\
\hline 11. & Cetraria islandica (L.) Ach. & soil & 2 & & 2 & & 2 \\
\hline 12. & Cladonia cariosa (Ach.) Spreng. & soil & 1 & & & & \\
\hline 13. & $\begin{array}{l}\text { Cladonia cervicornis subsp. verticillata } \\
\text { (Hoffm.) Ahti }\end{array}$ & soil & 2 & & & & \\
\hline 14. & Cladonia coniocraea auct. & bark & 1 & & & & \\
\hline 15. & Cladonia fimbriata (L.) Fr. & soil & 1 & & & & \\
\hline 16. & Cladonia furcata (Huds.) Schrad. & soil & 3 & & 3 & 2 & \\
\hline 17. & Cladonia glauca Flörke & soil & 2 & & & 2 & 3 \\
\hline 18. & Cladonia pocillum (Ach.) Grognot & soil, bryophytes & 3 & & 3 & 3 & \\
\hline 19. & Cladonia pyxidata (L.) Hoffm. & soil, bryophytes & 3 & 2 & 3 & 3 & 2 \\
\hline 20. & Cladonia rangiformis Hoffm. & soil & 1 & & 2 & & \\
\hline 21. & Cladonia subulata (L.) Weber & soil & & & 2 & 2 & \\
\hline
\end{tabular}




\begin{tabular}{|c|c|c|c|c|c|c|c|}
\hline 22. & Cladonia symphycarpia (Flörke) Fr. & soil & 2 & 2 & 2 & 2 & \\
\hline 23. & $\begin{array}{l}\text { Coeniogonium pineti (Ach.) Lücking \& } \\
\text { Lumbsch }\end{array}$ & bark & 1 & & & 3 & \\
\hline 24. & Collema limosum (Ach.) Ach. & soil & 2 & & & & \\
\hline 25. & Collema tenax (Sw.) Ach. & soil & 1 & & & 1 & 2 \\
\hline 26. & Diploschistes muscorum (Scop.) R. Sant. & $\begin{array}{l}\text { Cladonia spp., } \\
\text { bryophytes }\end{array}$ & 3 & & 3 & 2 & \\
\hline 27. & Diploschistes scruposus (Schreb.) Norm. & stones & 1 & & & 2 & \\
\hline 28. & Endocarpon pusillum Hedw. & soil & & & & 1 & \\
\hline 29. & Hypocenomyce scalaris (Ach.) M. Choisy & bark & 1 & & & & 2 \\
\hline 30. & Hypogymnia physodes (L.) Nyl. & bark & 1 & & & 2 & \\
\hline 31. & Lecania cyrtella (Ach.) Th. Fr. & Dianthus sp. & 1 & & & & \\
\hline 32. & Lecanora albescens (Hoffm.) Branth \& Rostr. & rock, stones & 2 & & 2 & & \\
\hline 33. & Lecanora conizaeoides Cromb. & bark & 2 & 3 & 3 & 3 & 3 \\
\hline 34. & Lecanora dispersa (Pers.) Sommerf. & rock, stones & 3 & & 3 & 2 & \\
\hline 35. & Lecanora hagenii (Ach.) Ach. & wood & 2 & & & & \\
\hline 36. & Lecanora saligna var. sarcopis (Ach.) Hillmann & bark & 2 & & 2 & 2 & \\
\hline 37. & Lecidella stigmatea (Ach.) Hertel \& Leuckert & rock & 1 & & & & \\
\hline 38. & Lepraria sp. & bark & & & 2 & & 2 \\
\hline 39. & Leptogium biatorinum (Nyl.) Leight. & soil & 2 & & & & \\
\hline 40. & Micarea denigrata (Fr.) Hedl. & wood & 1 & & & 2 & \\
\hline 41. & Micarea prasina Fr. & bark & 2 & 3 & & & 3 \\
\hline 42. & $\begin{array}{l}\text { Mycobilimbia tetramera (De Not.) Vitik., Ahti, } \\
\text { Kuusinen, Lommi \& T. Ulvinen }\end{array}$ & soil, bryophytes & 3 & & & 3 & \\
\hline 43. & Myxobilimbia sabuletorum (Schreb.) Hafellner & soil, bryophytes & 1 & & & & \\
\hline 44. & Parmelia sulcata Taylor & bark & & & 1 & & \\
\hline 45. & Peltigera didactyla (With.) J.R. Laundon & soil, bryophytes & 2 & & & 2 & \\
\hline 46. & Peltigera rufescens (Weiss) Humb. & soil & 2 & & 3 & 2 & \\
\hline 47. & Phaeophyscia nigricans (Flörke) Moberg & stones & & & 1 & & \\
\hline 48. & Phaeophyscia orbicularis (Neck.) Moberg & stones & & & 2 & & \\
\hline 49. & Physcia adscendens (Fr.) H. Olivier & stones & & & 2 & & \\
\hline 50. & Physcia caesia (Hoffm.) Fürnr. & rock, stones & 2 & & & & \\
\hline 51. & Physcia tenella (Scop.) DC. & bark & 1 & & & & \\
\hline 52. & $\begin{array}{l}\text { Placynthiella icmalea (Ach.) Coppins \& P. } \\
\text { James }\end{array}$ & bark & 1 & & & 2 & 2 \\
\hline 53. & Polyblastia albida Arnold & rock & 1 & & & & \\
\hline 54. & Porpidia crustulata (Ach.) Hertel \& Knoph & stones & 1 & & & 2 & \\
\hline 55. & Protoblastenia rupestris (Scop.) J.Steiner & rock, & 1 & & & & \\
\hline 56. & Protoparmeliopis muralis (Schreb.) Choisy & rock, stones & 1 & & & & \\
\hline 57. & Sarcosagium campestre (Fr.) Poetsch \& Schied. & soil, bryophytes & 3 & & & 2 & \\
\hline 58. & Scoliciosporum chlorococcum (Stenh.) Vězda & bark & 3 & 3 & 3 & 3 & 3 \\
\hline 59. & Scoliciosporum umbrinum (Ach.) Arnold & stones & 2 & & & & \\
\hline 60. & Steinia geophana (Nyl.) Stein & soil, bryophytes & 3 & & & & \\
\hline 61. & Stereocaulon incrustatum Flörke & soil & 2 & & & & \\
\hline 62. & Strangospora moriformis (Ach.) Stein & wood & 1 & & & & \\
\hline 63. & Thelidium papulare (Fr.) Arnold & stones & 1 & & & & \\
\hline 64. & Trapelia coarcatata $(\mathrm{Sm}$.$) M. Choisy in Werner$ & stones & 1 & & 2 & 2 & \\
\hline 65. & Trapelia placodioides Coppins \& P. James & stones & 1 & & & & \\
\hline 66. & Trapeliopsis flexиosa (Fr.) Coppins \& P. James & soil, bryophytes & 2 & & & 2 & \\
\hline 67. & Verrucaria aethiobola Wahlenb. & rock, stones & 2 & 2 & 2 & 2 & \\
\hline 68. & Verrucaria bryoctona (Th. Fr.) Orange & soil, bryophytes & 2 & & 2 & 2 & \\
\hline 69. & Verrucaria dolosa Hepp & rock, stones & 2 & & 2 & 2 & \\
\hline 70. & Verrucaria fatrana Servít & stones & & & 2 & & \\
\hline 71. & Verrucaria muralis Ach. & stones, pebbles & 3 & 2 & 3 & 3 & 2 \\
\hline 72. & Verrucaria nigrescens Pers. & stones, pebbles & 3 & & 2 & 2 & \\
\hline 73. & Verrucaria obfuscans Nyl. & stones & & & & 2 & \\
\hline 74. & Verrucaria procopii Servít & stones, pebbles & 2 & & 2 & & \\
\hline 75. & $\begin{array}{l}\text { Vezdaea aestivalis (Ohlert) Tscherm.-Woess \& } \\
\text { Poelt }\end{array}$ & soil, bryophytes & 1 & & 2 & 1 & \\
\hline 76. & Vezdaea leprosa (P. James) Vězda & soil, bryophytes & 1 & 2 & 2 & 2 & \\
\hline
\end{tabular}


A clearer picture of lichens is completed by 13 other species published earlier: Leucocarpia biatorella (Kiszka, Kościelniak 2006), Thelocarpon imperceptum (Kiszka 2006), Cetraria aculeata, Cladonia foliacea, Sarcogyne regularis and Thelidium velutinum (Kiszka, Szarek--Uukaszewska 2006), Micarea botryoides, M. micrococca (Czarnota 2007), Cladonia squamosa, C. arbuscula subsp. mitis, Lepraria elobata, L. jackii and Candelariella reflexa (Pawlik-Skowrońska et al. 2008). Studied area, in spite of its serious environmental transformation, can be characterized by the lichen species richness, but the number of species on a particular site varies according to surface, size, local edaphic conditions, degree of transformation. Only four species were noted from all five study sites, namely Cladonia pyxidata, Lecanora conizaeoides, Scoliciosporum chlorococcum and Verrucaria muralis. Candelariella aurella, Cladonia symphycarpia, Vezdaea leprosa and Verrucaria aethiobola were noted from four sites, 18 species from 3 sites, and 33 from only one. The highest diversity, 69 species, was found in Bolesław, of which 25 were only found at that site. Species abundance also varies, and most of them are rare and very rare species. They form the most interesting part of the lichen biota and give the studied area distinctive and characteristic features.

Taxonomically the most numerous groups are represented by Cladonia and Verrrucaria, with 13 and 8 species respectively. Morphologically, crustose lichens are dominant (62 species), many of which have small, often inconspicuous thalli; some are pioneer species, with an ability of to rapidly colonize rocks and soils. Foliose forms are represented by 17 species, and only 10 species have fruticose forms.

Every type of substrate available for lichens was investigated. Terricolous lichens (40 species), growing directly on soil or on mosses, or plant debris, were dominant. Diploschistes muscorum is particularly interesting due to its specific biology: in the first phase of the development it grows on other lichen thalli (especially on Cladonia species), but afterwards colonizes plant debris, soil or gravel. Epilithic lichens (29 species) are found on rock exposures, gravel, small stones and local ore, as well as imported building materials. Only small fraction of recorded species were epiphytic due to the shortage of forest complexes or old trees. At the same time, epiphytic lichens are most vulnerable to atmospheric pollution, so were represented by common, toxitolerant species such as Scoliciosporum chlorococcum and Lecanora conizaeoides. Hypogymnia physodes rarely occurs and Parmelia sulcata was noted only once. Due to the lack of suitable habitats, epixylic lichens are also scarce, but on small pieces of wood lying on the ground, Lecanora hagenii, Micarea denigrata and Strangospora moriformis were noted.

\section{DISCUSSION}

The number of species noted from zinc-lead ore-bearing areas in Poland is relatively high and can be compared to analogous lists from other European areas. Purvis and Halls (1996) mention 61 species of epigeic lichens characteristic of lead/zincrich environments from the United Kingdom, Belgium, the Netherlands, France and Germany. The species composition of lichen on metalliferous sites is very diverse 
and depends not only on the heavy metals present, but also on other edaphic characteristics, such as the chemical and physical features of the substrate (Cuny et al. 2004) and local microclimatic conditions. The biodiversity depends on the ore type and its chemical composition, post-mining waste granularity, storage method, land restoration procedures, and level of air pollution.

The current status of the environment in the vicinity of mines and heavy metal processing works does not favour epiphytic lichens, especially the toxic effect of sulfur dioxide (Kiszka 1993) which is exacerbated by high concentrations of heavy metals in the air (Godzik 1993). Studies carried on selected epiphytic lichen species from Bukowno showed high accumulations of $\mathrm{Zn}$ and $\mathrm{Pb}$ in their thalli (PawlikSkowrońska et al. 2008). Other features can be observed in the case of terricolous and epilithic species which rapidly and effectively colonize such substrates. Some, for example Protoparmeliopsis muralis, are common in various anthropogenic habitats. Others, of similar characteristics, but rarely noted due to their inconspicuous size and short existence, such as Steinia geophana and Sarcosagium campestre, are ruderals (Gilbert 1990). Vezdaea leprosa and V. aestivalis, recently found on many sites in Poland (Czarnota, Kiszka 2004), were frequently noted, and other species, regularly observed in Europe on $\mathrm{Zn}$ and $\mathrm{Pb}$ substrates, included Bacidia bagliettoana, Cladonia cariosa, C. glauca, C. furcata, C. rangiformis, Collema tenax, Diploschistes muscorum, Myxobilimbia sabuletorum, Scoliciosporum umbrinum and Trapelia coarctata. Yet, it would be hard to classify which of them are obligatory metallophytes and which are metallotolerant. It is though doubtless that Diploschistes muscorum is simultaneously tolerant and indicator for $\mathrm{Zn}$ and $\mathrm{Pb}$ presence in the substrate, species very frequent on the studied area. In the case of fruticose species, Cetraria islandica, C. aculeata and many Cladonia species, as well as several Stereocaulon species, especially $S$. nanodes, are characteristic of zinc and lead habitats. In Poland, only Stereocaulon incrustatum was noted, but not recorded from the similar areas; in the studied area it is quite common and forms a large population, with high concentration of $\mathrm{Zn}$ and $\mathrm{Pb}$ in their thalli (Pawlik-Skowrońska et al. 2008).

In spite of the high level of environment degradation and pollution, the postmining and zinc-lead ore processing areas, support a number of unique and exceptional lichens. This specific feature of the ore-bearing part of the Silesian-Kraków Upland is manifested by the presence of several interesting plant species, with the extremely rare Biscutella laevigata, recorded only from Tatra Mountains (Wierzbicka, Pielichowska 2004) or Arabidopsis halleri, which accumulates extremely high concentrations of various heavy metals (Pauwels et al. 2006). From a lichenological point of view, apart from lichen species mentioned above, mention should be made of other rarities in Poland, namely Leptogium biatorinum, Arthonia exilis, Endocarpon pusillum, Collema limosum, Polyblastia albida, Thelidium papulare and Verrucaria fatrana. Species protected by law, such as Cetraria aculeata, $C$. islandica, Peltigera didactyla, P. rufescens and Stereocaulon incrustatum were also recorded, and seven species listed are endangered, with EN, VU and NT threat categories (Cieśliński et al. 2006). Two species, Peltigera rufescens and $P$. didactyla have especially interesting ecology, as they contain symbiotic cyanobacteria in their thalli, with the ability to fix atmospheric nitrogen, and as such are an important part of trophic chain.

Apart from the species defined as toxitolerant, genuine lichen rarities, such as Peltigera venosa, normally an arctic-alpine species, can be found on metalliferous 
sites in lowland areas (Purvis, Halls 1996); montane species were also found in postmining, lowland areas in Poland. Leucocarpia biatorella (Kiszka, Kościelniak 2006), to date known only from high elevations in the Tatras and Western Beskidy Mts. (Olech 1999; Flakus 2007), was also recorded. Another species, Agonimia tristicula, found in the study area, although widely distributed in some parts of Europe, is rare in Poland where to date it has only been recorded from the Carpathians (Olech, Kiszka 1999; Kościelniak 2004; Flakus 2007). The extremely rare terricolous Thelocarpon imperceptum was also found on a restored post-mining site in the vicinity of Bolesław (Kiszka 2006); it is exceptionally rare in Europe, to date being recorded only from Switzerland (locus classicus) and Russia (Salisbury 1966), and recently from the Netherlands (van den Boom 2000).

\section{CONCLUSIONS}

The studies herewith provide a basis for the statement that the post-mining areas of the Silesian-Kraków Upland is a unique region for lichen species, not only for Poland, but also at the European scale. These studies are on-going within the project "Vegetation of calamine soils and its importance for biodiversity and landscape conservation in post-mining areas" (FM EEA PL 0265). This work will be crucial for a better understanding of ecosystem functioning under stress conditions in areas subjected to post-mining and post-processing zinc-lead ores. At the same time, the complex character of these sites, including various edaphic factors, will increase our knowledge of the ecological conditions and the tolerance of heavy metal concentrations by various species, and the value of particular lichen species as bioindicators. A further aim of these studies is to find suitable methods for biodiversity restoration of degraded areas. Effective restoration may in turn provide an opportunity for the continued existence of many interesting lichen species.

Polish zinc-lead ore bearing areas, due to the presence of numerous interesting species, including lichen species, generate particular environmental conditions with exceptional biocenosis representing the heritage of regional culture. The lichen species present in the studied area are one of the specialized elements of low grasslands the community Violetea calaminariae, supported on soils with above average heavy metal concentrations. These habitats are listed as rare and endangered in the Habitats Directive (Council Directive 92/43/EEC on the Conservation of natural habitats and of wild fauna and flora) and therefore protected in most of Western Europe. In Poland, those areas were often devastated. Currently, the situation is only slightly better, but as interest of zinc-lead ore bearing areas increase, some have been included in the Natura 2000 network.

Acknowledgements. We are greatly indebted to Professor Mark R. D. Seaward (University of Bradford) for his kindness and valuable comments for the manuscript improvement. We also thank an anonymous reviewer for very detailed remarks. Part of this research was supported by the project FM EEA PL 0265 (Financial Mechanism of European Economic Area). 


\section{REFERENCES}

Aptroot A., Boom van den P. P. G. 1998. Pyrenocollema chlorococcum, a new species with a chlorococcoid photobiont from zinc-contaminated soils and wood. Cryptogamie, Bryologie-Lichénologie 19: 193-196.

Boom van den P. P. G. 2000. Some interesting records of lichens and lichenicolous fungi from The Netherlands IV. Österreichische Zeitschrift für Pilzkunde 9:141-145.

Cieśliński S., Czyżewska K., Fabiszewski J. 2006. Red List of the lichens in Poland. (In:) Z Mirek, K. Zarzycki, W. Wojewoda, Z. Szeląg (eds). Red list of plants and fungi in Poland, 3. ed.: 71-89. W. Szafer Institute of Botany, Polish Academy of Sciences, Kraków.

Coppins B. J., Boom van den P. P. G. 1995. Micarea confuse, a new species from zinc- and cadmiumcontaminated soils in Belgium and The Netherlands. Lichenologist 27: 81-90.

Cuny D., Denayer F.-O., Foucault de B., Schumacker R., Colein P., Haluwyn van C. 2004. Patterns of metal soil contamination and changes in terrestrial cryptogamic communities. Environmental Pollution 129: 289-297.

Czarnota P. 2007. The lichen genus Micarea (Lecanorales, Ascomycota) in Poland. Polish Botanical Studies 23: 1-199.

Czarnota P., Kiszka J. 2004. Vezdaea aestivalis (Ohlert) Tscherm.-Woess \& Poelt. (In:) U. Bielczyk, S. Cieśliński, W. Fałtynowicz (eds). Atlas of the geographical distribution of lichens in Poland 4: 107110. W. Szafer Institute of Botany, Polish Academy of Sciences, Kraków.

Dobrzańska J. 1955. Badania florystyczno-ekologiczne nad roślinnością galmanową okolic Bolesławia i Olkusza. Acta Soc. Bot. Pol. 24: 357-408.

Fałtynowicz W. 2003. The lichens, lichenicolous and allied fungi of Poland. An annotated checklist. (In:) Z. Mirek (ed.). Biodiversity of Poland 6. W. Szafer Institute of Botany, Polish Academy of Sciences, Kraków, 435 pp.

Flakus A. 2007. Lichenized and lichenicolous fungi from mylonitized areas of the subnival belt in the Tatra Mountains (Western Carpathians). Ann. Bot. Fenn. 44: 427-449.

Gilbert O. L. 1990. The lichen flora of urban wasteland. Lichenologist 22: 87-101.

Godzik B. 1993. Heavy metals content in plants from zinc dumps and reference areas. Polish Botanical Studies 5: 113-132.

Heibel E. 1999. Flechtenvegatation auf Schwermetallstandorten in Nordrhein-Westfalen. (In:) A. Pardey (ed.). Naturschutz-Rahmenkonzeption Galmeifluren NRW. LÖBF-Schriftenreihe 16: 49-72.

Jędrzejczyk M. 2004. Zróżnicowanie flory naczyniowej obszarów galmanowych Monokliny ŚląskoKrakowskiej. Doctoral thesis. Uniwersytet Śląski. Katowice, 132 pp.

Jędrzejczyk-Korycińska M. 2006. Floristic diversity in calamine areas of the Silesia-Cracow Monocline. Biodiv. Res. Conserv. 3/4: 340-343.

Kauff F., Büdel B. 2005. Ascoma ontogeny and apothecial anatomy in the Gyalectaceae (Ostropales, Ascomycota) support in the re-establishment of the Coenogoniaceae. Bryologist 108: 272-281.

Kiszka J. 1993. Wpływ emisji miejsko-przemysłowych na florę porostów Górnego Śląska i okolicy. Studia Ośrodka Dokumentacji Fizjograficznej 21: 183-218.

Kiszka J. 2003. Porosty hałd cynkowo-ołowiowych w Bolesławiu koło Olkusza. (In:) J. Lach (ed.). Dynamika zmian środowiska geograficznego pod wpływem antropopresji. Instytut Geografii, Zakład Ochrony i Kształtowania Środowiska Przyrodniczego Akademia Pedagogiczna im. KEN, Kraków: 193-199.

Kiszka J. 2006. Thelocarpon imperceptum i możliwości jego ochrony w Polsce. (In:) Z. Mirek, E. Cieślak, B. Paszko, W. Paul, M. Ronikier (eds). Rzadkie, ginące i reliktowe gatunki roślin i grzybów, problemy zagrożenia i ochrony bioróżnorodności flory Polski. Materiały Ogólnopolskiej Konferencji Naukowej 30-31 maja 2006. Instytut Botaniki im. W. Szafera PAN, Zakład Systematyki Roślin Naczyniowych, Akademia Rolnicza im. H. Kołłątaja Wydział Leśny, Kraków: 90.

Kiszka J., Kościelniak R. 2006. Localities of the high-mountain species Leucocarpia biatorella in the Silesian Upland (southern Poland). (In:) A. Lackovičová, A. Guttová, A. Lisická, P. Lizoň (eds). Central European lichens. Diversity and threat: 325-329. Mycotaxon, Ithaca.

Kiszka J., Szarek-Łukaszewska G. 2006. Porosty terenów po górnictwie cynkowo-ołowiowym w Bukownie koło Olkusza (Polska południowa). Chrońmy Przyr. Ojczystą. http://www.iop.krakow.pl/iop. asp?0403: $1-4$.

Kościelniak R. 2004. Porosty (Lichenes) Bieszczadów Niskich. Fragm. Florist. Geobot. Suppl. 5: 1-164. 
Lumbsch H. T., Heibel E. 1998. Coppinsia minutissima, a new genus and species in the Agyriaceae from the British Isles. Lichenologist 30: 95-101.

Mirek Z., Piękoś-Mirkowa H., Zając A., Zając M. 2002. Flowering Plants and Pteridophytes of Poland. A checklist. (In:) Z. Mirek (ed.). Biodiversity of Poland. 1. W. Szafer Institute of Botany, Polish Academy of Sciences, Kraków, 442 pp.

Molenda D. 1963. Górnictwo kruszcowe na terenie złóż śląsko-krakowskich do połowy XVI w. Studia i materiały z Historii Kultury Materialnej XV, Studia z Dziejów Górnictwa i Hutnictwa VIII. Ossolineum, Wrocław-Warszawa-Kraków, 425 pp.

Olech M. 1999. Leucocarpia biatorella (Arnold) Vězda (In:) S. Cieśliński, W. Fałtynowicz (eds). Atlas of the geographical distribution of lichens in Poland 2: 35-36. W. Szafer Institute of Botany, Polish Academy of Sciences, Kraków.

Olech M., Kiszka J. 1999. Agonimia tristicula (Nyl.) Zahlbr. (In:) S. Cieśliński, W. Fałtynowicz (eds). Atlas of the geographical distribution of lichens in Poland 2: 7-9. W. Szafer Institute of Botany, Polish Academy of Sciences, Kraków.

Pawlik-Skowrońska B., Wójciak H., Skowroński T. 2008. Heavy metal accumulation, resistance and physiological status epigeic and epiphytic lichens inhabiting $\mathrm{Zn}$ and $\mathrm{Pb}$ polluted areas. Pol. J. Ecol. 56: 195-207.

Paus S. M. 1997. Die Erdflechtenvegetation nordwestdeutschlands und einiger Randgebiete. Biblioth. Lichenol. 66: 1-222.

Pauwels M., Frérot H., Bonnin I., Saumitou-Laprade P. 2006. A broad-scale analysis of population differentiation for $\mathrm{Zn}$ tolerance in an emerging model species for tolerance study: Arabidopsis halleri (Brassicaceae). J. Evol. Biol. 19: 1838-1850.

Purvis O. W., Halls C. 1996. A review of lichens in metal-enriched environments. Lichenologist 28: 571601.

Salisbury G. 1966. A monograph of the lichen genus Thelocarpon Nyl. Lichenologist 3:175-196.

Seaward M. R. D., Bylińska E. A. 1980. Plant-substrate correlations in bioindication studies of metals. (In:) R. Schubert, J. Schuh (eds). Methodische und theoretische Grundlagen der Bioindikation, p. 45-51. Martin-Luther-Universität, Halle-Wittenburg: 45-51.

Szarek-Łukaszewska G., Grodzińska K. 2008. Naturalna roślinność w rejonach starych zwałowisk odpadów po górnictwie rud $\mathrm{Zn}-\mathrm{Pb}$ w okolicy Bolesławia i Bukowna (region śląsko-krakowski; południowa Polska). Przegląd Geologiczny 56: 528-531.

Wierzbicka M. 2002. Przystosowania roślin do wzrostu na hałdach cynkowo-ołowianych okolic Olkusza. Kosmos 51: 139-150.

Wierzbicka M., Pielichowska M. 2004. Adaptation of Biscutella laevigata L., a metal hyperaccumulator, to growth on a zinc-lead waste heap in southern Poland. I. Differences between waste-heap and mountain populations. Chemosphere 54: 1663-1674.

Wirth V. 1972. Die Silikatflechten-Gemeinschaften in Ausseralpinen Zentraleuropa. Dissertationes Botanicae 17: 1-305.

Żabiński W. 1960. Charakterystyka mineralogiczna strefy utlenienia śląsko-krakowskich złóż kruszców cynku i ołowiu. Prace Geologiczne 1: 1-173.

Żabiński W. 1978. Charakterystyka mineralogiczna rud tlenkowych. Prace Instytutu Geologii 83: 223-227. 


\section{Porosty na terenach pogórniczych rud cynkowo-ołowiowych}

\section{Streszczenie}

Praca prezentuje wyniki badań lichenologicznych przeprowadzonych na wybranych powierzchniach Wyżyny Śląsko-Krakowskiej związanych z eksploatacją rud cynkowo-ołowiowych. Lista porostów tego terenu liczy 89 taksonów, z których 76 zawartych jest w tabeli 1 . Pomimo trudnych warunków siedliskowych (brak wody oraz niektórych składników pokarmowych, wysoka zawartość metali ciężkich - głównie cynku, ołowiu i kadmu, - silna insolacja oraz silne działania wiatrów), występuje tu bardzo zróżnicowana i specyficzna biota porostów. Porosty były badane na wszystkich dostępnych substratach. Najmniej liczne są epifity i epiksylity, ograniczone do kilku najpospolitszych, toksytolerancyjnych gatunków. Dominują gatunki naziemne i naskalne, z których te ostatnie rosną głównie na kamieniach i drobnych kamykach. Wśród form morfologicznych zdecydowanie liczebną przewagę mają porosty skorupiaste, choć o fizjonomii zbiorowisk decydują porosty krzaczkowate, zwłaszcza Cladonia spp., które występują obficie i tworzą duże populacje. $\mathrm{Z}$ nielicznych form listkowatych obecne są Peltigera rufescens i $P$. didactyla, które poprzez zdolność wiązania wolnego azotu przez symbiotyczne sinice, są ważnym ogniwem łańcucha troficznego. Występują gatunki związane z substratami zawierającymi cynk i ołów, które mogą być wskaźnikami ich obecności w podłożu: Diploschistes muscorum, Sarcosagium campestre, Steinia geophana, Vezdaea aestivalis i V. leprosa. Wiele spośród odnotowanych porostów to gatunki rzadkie lub bardzo rzadkie w Polsce, pięć z nich podlega ochronie prawnej, a siedem - znajduje się na krajowej czerwonej liście. Badany teren jest również ostoją rzadkich porostów górskich, na przykład Leucocarpia biatorella oraz bardzo rzadkiego w Europie Thelocarpon imperceptum. Analizowana lichenobiota jest porównywalna ze składem gatunkowym porostów z innych terenów pogórniczych Europy. 